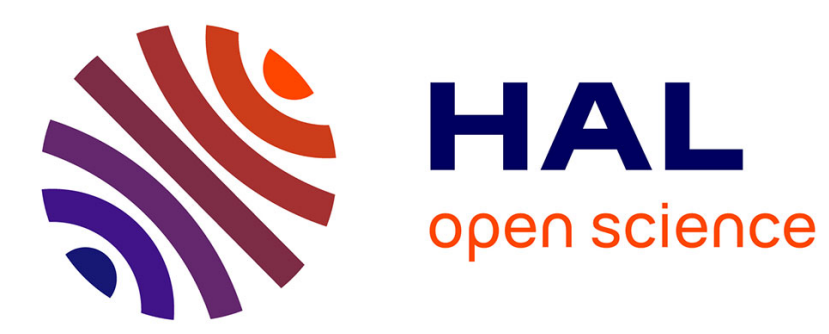

\title{
Pump Hydro Energy Storage systems (PHES) in groundwater flooded quarries
}

\author{
Angélique Poulain, Jean-Raynald de Dreuzy, Pascal Goderniaux
}

\section{To cite this version:}

Angélique Poulain, Jean-Raynald de Dreuzy, Pascal Goderniaux. Pump Hydro Energy Storage systems (PHES) in groundwater flooded quarries. Journal of Hydrology, 2018, 559, pp.1002-1012. 10.1016/j.jhydrol.2018.02.025 . insu-01739484

\section{HAL Id: insu-01739484 \\ https://hal-insu.archives-ouvertes.fr/insu-01739484}

Submitted on 21 Mar 2018

HAL is a multi-disciplinary open access archive for the deposit and dissemination of scientific research documents, whether they are published or not. The documents may come from teaching and research institutions in France or abroad, or from public or private research centers.
L'archive ouverte pluridisciplinaire HAL, est destinée au dépôt et à la diffusion de documents scientifiques de niveau recherche, publiés ou non, émanant des établissements d'enseignement et de recherche français ou étrangers, des laboratoires publics ou privés. 


\section{Accepted Manuscript}

Research papers

Pump Hydro Energy Storage systems (PHES) in groundwater flooded quarries

Angélique Poulain, Jean-Raynald De Dreuzy, Pascal Goderniaux

PII:

S0022-1694(18)30101-X

DOI:

https://doi.org/10.1016/j.jhydrol.2018.02.025

Reference:

HYDROL 22574

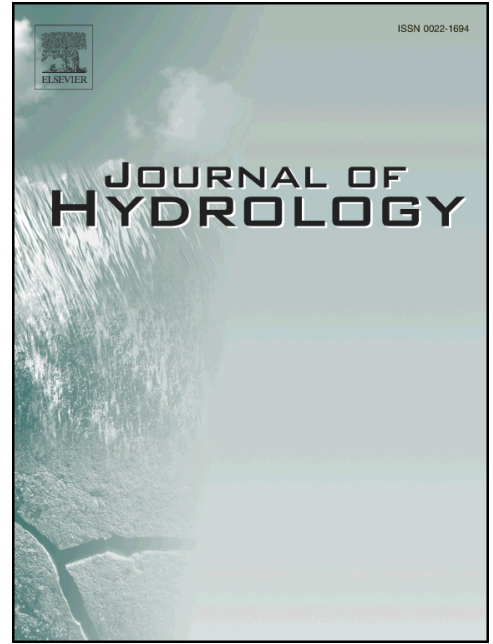

To appear in:

Journal of Hydrology

Received Date:

14 September 2017

Revised Date:

5 February 2018

Accepted Date:

12 February 2018

Please cite this article as: Poulain, A., De Dreuzy, J-R., Goderniaux, P., Pump Hydro Energy Storage systems (PHES) in groundwater flooded quarries, Journal of Hydrology (2018), doi: https://doi.org/10.1016/j.jhydrol.2018.02.025

This is a PDF file of an unedited manuscript that has been accepted for publication. As a service to our customers we are providing this early version of the manuscript. The manuscript will undergo copyediting, typesetting, and review of the resulting proof before it is published in its final form. Please note that during the production process errors may be discovered which could affect the content, and all legal disclaimers that apply to the journal pertain. 


\title{
Pump Hydro Energy Storage systems (PHES) in groundwater flooded quarries
}

\author{
Manuscript prepared for submission to Journal of Hydrology
}

Initial submission - September 2017

Revised manuscript - February 2018

Angélique POULAIN ${ }^{1}$, Jean-Raynald DE DREUZY ${ }^{2}$, Pascal GODERNIAUX ${ }^{1}$

${ }^{1}$ Geology and Applied Geology

University of Mons

Rue de Houdain, 9

7000 Mons

Belgium

${ }^{2}$ Geosciences Rennes

University of Rennes 1

Campus Beaulieu

35000 Rennes

France

*Corresponding author: Angelique.Poulain@umons.ac.be 


\begin{abstract}
Pump storage hydroelectricity is an efficient way to temporarily store energy. This technique requires to store temporarily a large volume of water in an upper reservoir, and to release it through turbines to the lower reservoir, to produce electricity. Recently, the idea of using old flooded quarries as a lower reservoir has been evoked. However, these flooded quarries are generally connected to unconfined aquifers. Consequently, pumping or injecting large volumes of water, within short time intervals, will have an impact on the adjacent aquifers. Conversely, water exchanges between the quarry and the aquifer may also influence the water level fluctuations in the lower reservoir. Using numerical modelling, this study investigates the interactions between generic flooded open pit quarries and adjacent unconfined aquifers, during various pump-storage cyclic stresses. The propagation of sinusoidal stresses in the adjacent porous media and the amplitude of water level fluctuations in the quarry are studied. Homogeneous rock media and the presence of fractures in the vicinity of the quarry are considered. Results show that hydrological quarry - rock interactions must be considered with caution, when implementing pump - storage systems. For rock media characterized by high hydraulic conductivity and porosity values, water volumes exchanges during cycles may affect significantly the amplitude of the water level fluctuations in the quarry, and as a consequence, the instantaneous electricity production. Regarding the impact of the pump storage cyclic stresses on the surrounding environment, the distance of influence is potentially high under specific conditions, and is enhanced with the occurrence of rock heterogeneities, such as fractures. The impact around the quarry used as a lower reservoir thus appears as an important constraining factor regarding the feasibility of pump - storage systems, to be assessed carefully if groundwater level fluctuations around the quarry are expected to bring up adverse effects. Results highlight opportunities and challenges to be faced, to implement pump - storage hydroelectricity systems in old flooded open pit quarries.
\end{abstract}

\title{
Keywords:
}

Pump Hydro Energy Storage systems; quarry - aquifer interactions; oscillatory pumping tests; groundwater; open pit. 


\section{Introduction and objectives}

The energetic production currently induces a lot of socio-economic and environmental challenges. Part of this production is more and more made from renewable energy sources, and the integration of this intermittent energy in the power distribution grids becomes problematic (Connolly, 2010). In this context, hydroelectricity is highly interesting because it constitutes an efficient way to temporarily store energy. This is actually needed for regulation purposes, to manage the variable energy demand and production across a day. Pump-storage systems generally consist of an upper and a lower reservoir. Water is pumped from the lower to the upper reservoir during periods of low energy demands. During high energy demand periods, water is released into the lower reservoir through turbines, to produce electricity. The period of the cycles is typically from one to a few hours. The amount of produced energy mainly depends on the elevation difference between the two reservoirs, and the volume of water involved. This technique thus requires very large water reservoirs. Some pump-storage systems have already been installed in different countries (Rehman et al., 2015). This kind of hydroelectric stations classically use impervious artificial water reservoirs and are connected to the high voltage power grids. Recently, the idea of using the numerous abandoned and flooded quarries or underground mines as storage reservoirs has been discussed (Figure 1). Due to the topographic context, these quarries and mines would generally be used as the lower reservoirs (Uddin and Asce, 2003). This would allow saving some reservoir construction costs, reproducing these systems in the many existing sites, and connecting them to the medium-voltage power grids (Madlener and Specht, 2013). Quarries and mines can however not be considered as impervious reservoirs. They are actually in close interaction with the adjacent rock medium (Figure 1). As a consequence, pumping or injecting large volumes of water in a quarry or a mine, within short time intervals, will inevitably induce an impact on the surrounding groundwater table. Reversely, under this kind of pumping and injection stresses, water exchanges between the flooded quarry and adjacent unconfined aquifers may also impact the amplitude of water level fluctuations in the lower reservoir. 


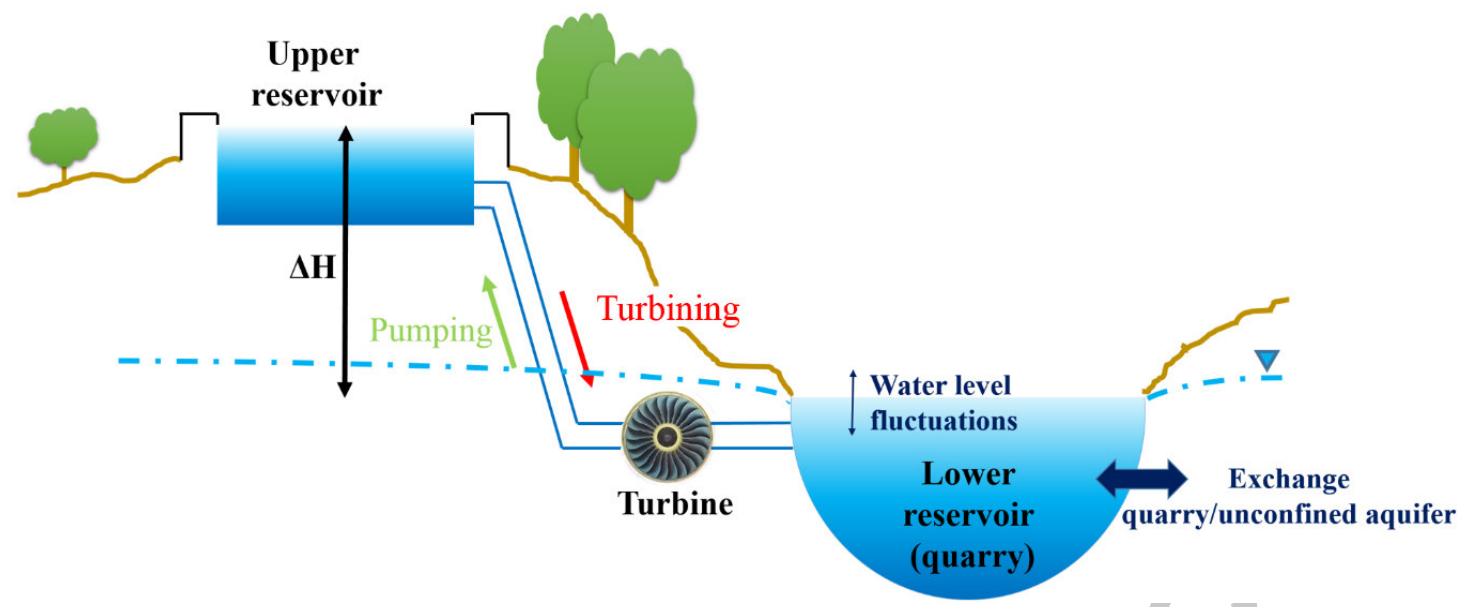

Figure 1. Simplified representation of a pump-storage system between an upper artificial reservoir and a flooded quarry (lower reservoir).

Studying the interactions between the flooded reservoir (quarry or mine) and the adjacent water table is crucial to decide on the feasibility of the projects. The water level fluctuations in the flooded quarry constitutes an important parameter of the hydroelectric production, because the drop of elevation between the water levels of two reservoirs defines the productivity of the system. These water level fluctuations must therefore be evaluated carefully, including the potential influence of the water exchanges between the reservoir and the rock medium. The fluctuations, induced in the reservoir, will propagate into the rock medium. The distance of propagation also has to be quantified, to determine the impact of pump-storage systems on the environment. This is necessary, for example to assess the cohabitation with other actors such as neighboring groundwater pumping areas. Similarly, soil stability problems, related to the subsidence or collapse of some weathered rocks in the vicinity of the quarry (Kaufmann and Quinif, 2002), may be caused or exacerbated by the induced fluctuations of the groundwater table.

Very few pump-storage systems, using permeable reservoirs, have been studied from a hydrogeological perspective. A few cases involving underground mines have been reported. For an example, (Severon, 2011) investigates the possibility of recycling some iron mines in pump-storage systems. Some underground mines may actually be interesting because they potentially enable a great elevation difference between the reservoirs (Pujades et al., 2016). However, these mines also generate some important questions regarding their stability, and almost all studies have focused on geomechanical problems (e.g. Lee and Song, 2003). Almost no research about pump-storage systems using flooded quarries is reported. A few hydrogeological studies involving quarries have been performed, but they focus on steady- 
state problems. As an example, Eberts and Bair (1990) have assessed the impact of quarry dewatering on long-term groundwater resources, according to the hydrogeological context. Lepage et al. (1999), have studied groundwater contamination issues induced by a landfill located in an old quarry in Canada and have highlighted the influence of the geological structures. Pump-storage systems are however different as they involve transient processes, with unusual frequencies of stresses in groundwater systems. Water is actually pumped or injected cyclically, over short time periods, varying from one to a few hours.

Recently, this kind of cyclic stresses has been investigated, through the development of oscillatory pumping tests (Bakhos et al., 2014; Bakker, 2009; Black and Kipp, 1981; Cardiff et al., 2013; Guiltinan and Becker, 2015; Rabinovich et al., 2015; Rasmussen et al., 2003; Renner and Messar, 2006). The approach is to obtain hydraulic parameter estimation, using the amplitude and phase shift of water level oscillations induced in a specific point, and propagated in the porous media. This approach appears to be useful in some specific conditions (Bakhos et al., 2014; Rasmussen et al., 2003). For example, when the intensity of the propagated signal becomes similar to the ambient noise, simple signal processing can differentiate and extract specific frequency components, and thus increase the resolution of the method. Although the context of these tests is different compared to pump-storage systems, the processes involved are similar. Oscillatory pumping tests have generally been used to estimate hydraulic properties in oil reservoirs, but they have also been applied and studied in groundwater reservoirs. Rasmussen et al. (2003) have performed oscillatory pumping field experiments in a confined, leaky and partially penetrating aquifer and estimated the hydraulic parameter values with an analytical solution. Black and Kipp (1981) have estimated the different ranges of hydraulic diffusivity, for which sinusoidal pumping tests can be applied, using the amplitude and phase shift of the measured signal in a homogeneous isotropic confined aquifer. Bakker (2009) studied the effect of aquifer heterogeneities on the response of a sinusoidal pumping sequence, using an analytic-element solution. The possibility to use oscillatory pumping test for hydraulic imaging is investigated by Cardiff et al. (2013) with oscillatory pumping tests performed in homogeneous and heterogeneous confined aquifer. Cardiff et al. (2013), Renner and Messar (2006) and Guiltinan and Becker (2015) highlight the influence of the frequency in the propagation of the induced stressed and in the investigated scale of the oscillatory pumping test.

All these studies have been performed considering confined aquifers. In the case of pump storage systems in open pit quarries, concerned aquifers are however mostly unconfined. To 
our knowledge, only one recent study has considered such aquifers. Using experimental field works, laboratory and analytical analyses, Rabinovich et al. (2015) have studied the dependence of the calculated hydraulic parameter values on the prescribed cyclic stresses frequency, in an unconfined aquifer.

The scale to be considered in pump-storage systems installed in large surface reservoirs is also very different from the system dimensions considered in previous studies. The typical size of open pit quarries is several tens or hundreds of meters. As a consequence, the scale to consider, the water flow rates to pump and inject, and the capacity effects to consider in the quarry are much more important, than in previously investigated experimental sites.

Considering this context, the general objective of this paper is to study the interactions between a flooded open pit quarry and an adjacent unconfined aquifer, during cyclic water pumping and injection in the quarry, for pump-storage system operations. We focus our attention on the water volumes exchanged between the quarry and the rock media, and on the environmental impact of the cyclic stresses on the surrounding aquifer. Numerical simulations are used to investigate different configurations, as a function of several sets of hydraulic parameters values. We consider the case of a homogeneous media, the presence of fractures, the influence of the cyclic stresses frequency and intensity, and the influence of the regional hydraulic gradient. The results are discussed regarding the feasibility of pump-storage storage systems as a function of the hydrogeological context of the open pit flooded quarries. 


\section{Methods}

\subsection{Conceptual model}

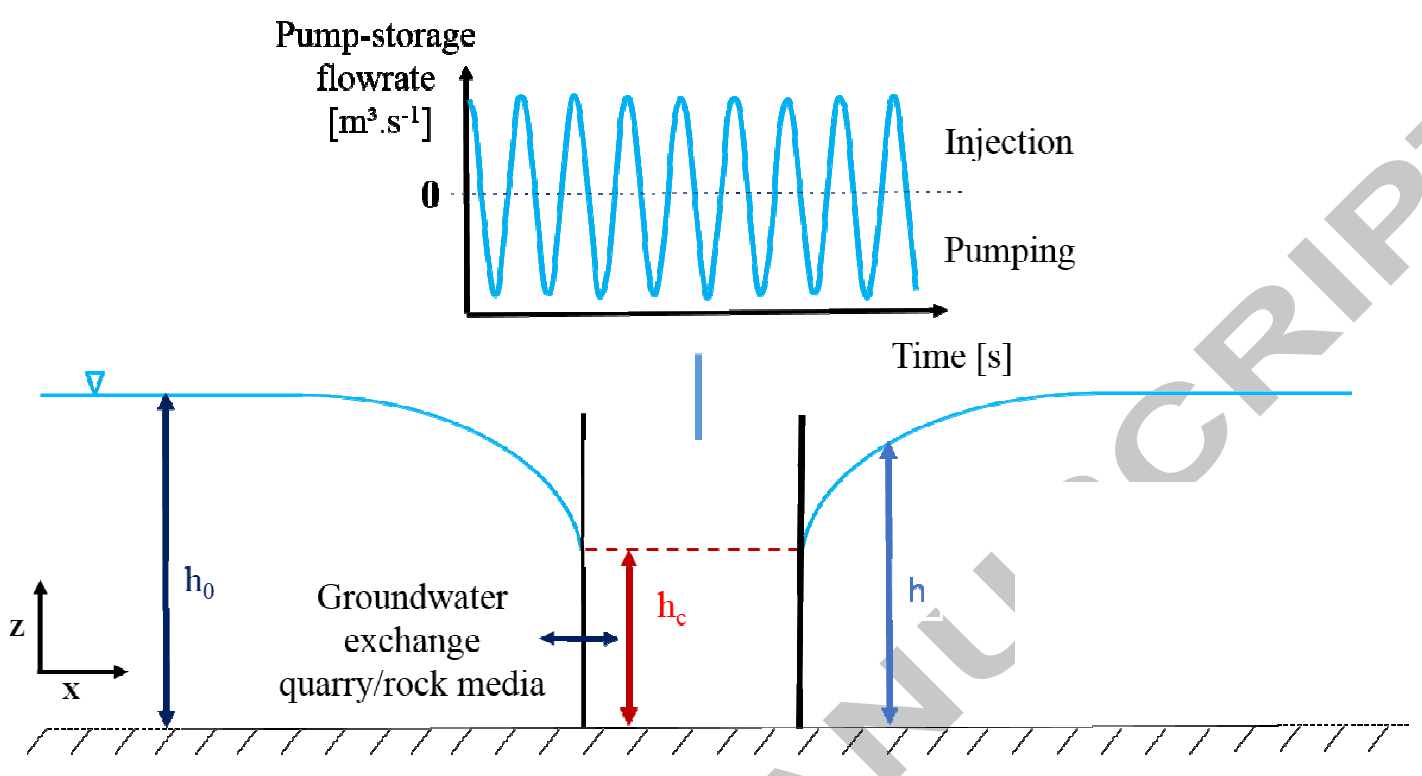

Figure 2. Conceptualization of a flooded quarry affected by cyclic stresses (water pumping and injection).

Figure 2 conceptualizes the system consisting of a flooded open pit quarry affected by cyclic stresses, and the surrounding rock media, where induced groundwater level variations propagate. The case of unconfined aquifers is exclusively considered. The limits of the system are chosen far enough from the quarry so that they have no influence on the studied processes. The quarry has a prismatic rectangular shape and is located at the center of the domain. The lower limit of the modelled area corresponds to the bottom of the quarry. Groundwater fluxes through the base of the quarry are consequently not considered. This case is frequently observed when the base of the quarry also corresponds to a geological limit. Cyclic stresses correspond to water pumping and injection in the open pit quarry. In this study, stresses are conceptualized as sinusoidal variations, as illutrated in Figure 2. Negative and positive values correspond to water pumping and injection, respectively. In a real pump-storage system, stresses would not be sinusoidal, as further discussed in Section 4. However, working with a sinusoidal signal presents some advantages (Bakhos et al., 2014; Cardiff et al., 2013; Rasmussen et al., 2003; Renner and Messar, 2006). The sinusoidal input signal is fully controlled and characterized by a unique frequency value, so that the output measured signal is easy to recognize and analyze. Results are also easier to compare with other studies, which have used the same kind of stresses. 


\subsection{General equations}

Assuming that flows are essentially horizontal, we model flows in 2D using the classical Dupuit-Forchheimer equations (Dupuit, 1863).

The flow equation within unconfined aquifers is:

$$
\frac{\mathrm{S}_{\mathrm{y}}}{\mathrm{K}} \frac{\partial \mathrm{h}}{\partial \mathrm{t}}=\nabla(\mathrm{h} \nabla \mathrm{h})
$$

with $\quad \mathrm{S}_{\mathrm{y}} \quad$ the specific yield [-]

$\mathrm{h}$ the variable groundwater head equal to the saturated thickness [m]

$\mathrm{t}$ the time [s]

$\mathrm{K}$ the hydraulic conductivity $\left[\mathrm{m} . \mathrm{s}^{-1}\right]$.

In the quarry we assume that the hydraulic head is uniformly equal to $h_{c}$ and can be directly derived from a simple flow balance of the pumped/injected water and of the interaction with the aquifer:

$$
\mathrm{S} \frac{\partial \mathrm{h}_{\mathrm{c}}}{\partial \mathrm{t}}=\mathrm{Q}_{\max } \sin \left(2 \pi \frac{\mathrm{t}}{\tau}\right)+\int_{\Gamma} \mathrm{Kh} \frac{\partial \mathrm{h}}{\partial \mathrm{n}} \mathrm{d} \Gamma
$$

where $\mathrm{S} \quad$ is the surface of the quarry $\left[\mathrm{m}^{2}\right]$

$\mathrm{Q}_{\max }$ is the maximum value of the sinusoidal flow rate imposed in the quarry $\left[\mathrm{m}^{3} \cdot \mathrm{s}^{-1}\right]$

$\tau \quad$ is the period of the imposed sinusoidal flow rate $[\mathrm{s}]$

$\mathrm{n} \quad$ is the unit vector normal to the limit of the quarry [-]

$\Gamma \quad$ is the contour of the quarry [-].

Continuity conditions are imposed at the interface $\Gamma$ between the aquifer and the quarry on the hydraulic head:

$$
\mathrm{h}(\mathrm{x}, \mathrm{t})=\mathrm{h}_{\mathrm{c}}(\mathrm{t}) \forall \mathrm{x} \in \Gamma .
$$

Initial conditions are imposed on the whole considered domain

$$
\mathrm{h}(\mathrm{x}, \mathrm{t}=0)=\mathrm{h}_{0} \forall \mathrm{x} \in \Omega
$$

where $\Omega$ is the entire domain [-]. 
The objective of this study is to assess the impact of the periodic pumping and injection flow rates on the water head variations in the quarry and in the surrounding rock environnement. To reach this objective, different specific output variables will be calculated and analyzed for several scenarios, as a function of the main hydraulic parameters.

The amplitude of the water level variations at any point of the modelled area can be expressed as in Equation 5. This amplitude is expected to change according to the hydraulic parameters of the rock media, and to the related quarry-groundwater interactions.

$$
\Delta \mathrm{h}(\mathrm{x})=\mathrm{h}_{\max }(\mathrm{x})-\mathrm{h}_{\min }(\mathrm{x})[\mathrm{m}] .
$$

More specifically, the amplitude of the water level variations in the quarry is noted as $\Delta \mathrm{h}_{\mathrm{c}}$.

$$
\Delta \mathrm{h}_{\mathrm{c}}=\mathrm{h}_{\mathrm{c}, \max }-\mathrm{h}_{\mathrm{c}, \min }[\mathrm{m}]
$$

The amplitudes of the hydraulic head fluctuations at any point of the model is used to define a 'distance of influence' of the pump-storage operations, in the rock media. This distance of influence is defined as the distance between the quarry walls and the point in the rock domain where the amplitude of the hydraulic head fluctuation is reduced by $99 \%$, compared to the theoretical amplitude of the water level fluctuations in the quarry, in absence of any water exchange between the quarry and the rock medium (i.e. in a quarry located in a totally impervious medium) (Equation 7):

$$
\begin{aligned}
& \mathrm{d}[\mathrm{m}] \text { : distance from the quarry wall to the point }(\mathrm{x}) \text {, where } \frac{\Delta \mathrm{h}(\mathrm{x})}{\eta_{\mathrm{c}}}=10^{-2}[-] \\
& \eta_{\mathrm{c}}=\frac{\mathrm{Q}_{\max } \tau}{\mathrm{S} \pi}[\mathrm{m}] .
\end{aligned}
$$

$\eta_{\mathrm{c}}$ represents the theoretical water level fluctuation in the quarry during a half period of sinusoidal pumping, in absence of any water exchange between the quarry and the rock medium.

\subsection{Dimensionless equations}

Several parameters related to the hydraulic properties, the size of the quarry and the sinusoidal stresses are involved in the equations. To reduce the number of parameters and simplify the analysis, non-dimensional parameters and variables have been introduced.

Dimensionless variables, related to the sinusoidal pumping imposed in the quarry, are introduced: 


$$
\overline{\mathrm{h}}=\frac{\mathrm{h}}{\eta_{\mathrm{c}}}[-] \quad \overline{\mathrm{h}}_{\mathrm{c}}=\frac{\mathrm{h}_{\mathrm{c}}}{\eta_{\mathrm{c}}}[-] \quad \overline{\mathrm{t}}=\frac{\mathrm{t}}{\tau}[-] .
$$

Incorporating these variables into Equations 1 to 4 leads to the following non-dimensional equations:

$$
\begin{aligned}
& \frac{\mathrm{S}_{\mathrm{y}}}{\mathrm{K}} \frac{\partial \overline{\mathrm{h}}}{\partial \overline{\mathrm{t}}} \frac{\eta_{\mathrm{c}}}{\tau}=\bar{\nabla}(\overline{\mathrm{h}} \bar{\nabla} \overline{\mathrm{h}}) \\
& \frac{\partial \overline{\mathrm{h}_{\mathrm{c}}}}{\partial \overline{\mathrm{t}}}=\pi \cdot \sin (2 \pi \overline{\mathrm{t}})+\frac{\mathrm{K} \eta_{\mathrm{c}} \tau}{\mathrm{s}} \int_{\bar{\Gamma}} \overline{\mathrm{h}} \frac{\partial \overline{\mathrm{h}}}{\partial \overline{\mathrm{n}}} \mathrm{d} \bar{\Gamma} \\
& \overline{\mathrm{h}}(\overline{\mathrm{x}}, \overline{\mathrm{t}})=\overline{\mathrm{h}_{\mathrm{c}}}(\overline{\mathrm{t}}) \forall \overline{\mathrm{x}} \in \bar{\Gamma} \\
& \overline{\mathrm{h}}(\overline{\mathrm{x}}, \overline{\mathrm{t}}=0)=\frac{\mathrm{h}_{0}}{\eta_{\mathrm{c}}} \forall \overline{\mathrm{x}} \in \bar{\Omega}
\end{aligned}
$$

Based on these equations, three non-dimensional parameters are defined.

$$
\begin{aligned}
& \overline{\mathrm{D}}=\frac{\tau \mathrm{K}}{\eta_{\mathrm{c}} \mathrm{S}_{\mathrm{y}}}[-] \\
& \overline{\mathrm{K}}=\frac{\mathrm{K} \tau \eta_{\mathrm{c}}}{\mathrm{S}}[-] \\
& \overline{\mathrm{h}_{0}}=\frac{\mathrm{h}_{0}}{\eta_{\mathrm{c}}}[-]
\end{aligned}
$$

$\overline{\mathrm{D}}$ is interpreted as a non-dimensional diffusivity of the aquifer, and does not depend on the quarry dimensions. $\overline{\mathrm{K}}$ is understood as a non-dimensional exchange capacity between the quarry and the aquifer. $\overline{\mathrm{h}_{0}}$ is the effective depth of the aquifer.

By substituting these non-dimensional parameters in Equations 10 to 13, the final nondimensional formulation of the problem is:

$$
\begin{aligned}
& \frac{1}{\overline{\overline{\mathrm{D}}}} \frac{\partial \overline{\mathrm{h}}}{\partial \overline{\mathrm{t}}}=\bar{\nabla}(\overline{\mathrm{h}} \bar{\nabla} \overline{\mathrm{h}}) \\
& \frac{\partial \overline{\mathrm{h}_{\mathrm{c}}}}{\partial \overline{\mathrm{t}}}=\pi \cdot \sin (2 \pi \overline{\mathrm{t}})+\overline{\mathrm{K}} \int_{\bar{\Gamma}} \overline{\mathrm{h}} \frac{\partial \overline{\mathrm{h}}}{\partial \overline{\mathrm{n}}} \mathrm{d} \bar{\Gamma} \\
& \overline{\mathrm{h}}(\overline{\mathrm{x}}, \overline{\mathrm{t}})=\overline{\mathrm{h}_{\mathrm{c}}}(\overline{\mathrm{t}}) \forall \overline{\mathrm{x}} \in \bar{\Gamma} \\
& \overline{\mathrm{h}}(\overline{\mathrm{x}}, \overline{\mathrm{t}}=0)=\overline{\mathrm{h}_{0}} \forall \overline{\mathrm{x}} \in \bar{\Omega}
\end{aligned}
$$

Similarly to the parameters, the specific output variables may be expressed in a nondimensional way.

$\overline{\Delta h_{c}}$ represents the amplitude of the water level fluctuations in the quarry, normalized by the 
theoretical amplitude in absence of any water exchange between the quarry and the rock medium:

$$
\overline{\Delta h_{c}}=\frac{\Delta \mathrm{h}_{c}}{\eta_{\mathrm{c}}}[-]
$$

$\overline{\mathrm{d}}$ is the distance of influence, normalized by the theoretical amplitude of the water level fluctuations in the quarry in absence of any water exchange between the quarry and the rock medium.

$$
\overline{\mathrm{d}}=\frac{\mathrm{d}}{\eta_{\mathrm{c}}} ;[-]
$$

\subsection{Numerical methods}

Equations 17 - 20 are solved using Modflow 2005 (Harbaugh, 2005). The modelled area, including the open pit quarry and the surrounding unconfined aquifer, is discretized using one layer of rectangular finite difference cells. As consequence, calculated groundwater fluxes are horizontal, and the Dupuit-Forchheimer approximatoin is considered. It enables to reduce the total number of cells and to prevent numerical problems related to saturation - desaturation of cells. Errors induced by Dupuit-Forchheimer approximation have been quantified by comparing multilayer and monolayer model results. The maximum difference in terms of groundwater fluxes remains below $2 \%$ when the drawdown induced in the quarry is comparable to the aquifer thickness.

The grid is composed by irregular rectangular cells. Next to the quarry, cells are squared with a width of $1 \mathrm{~m}$. Away from the quarry, cells are rectangular with a size increasing with the distance to the quarry walls, by a factor of 1.05 every row and column. This mesh ensures higher accuracy next to the quarry, where groundwater variations are expected to be higher. In the quarry, the hydraulic parameters have been specified to represent the volume of water and the absence of rock medium. The specific yield is thus equal to 1 and the hydraulic conductivity has been fixed several orders of magnitude larger than the maximum aquifer hydraulic conductivity investigated. In these conditions, the simulated hydraulic head field in the quarry can be considered as uniform.

Constant groundwater head boundary conditions are prescribed on the external limits of the model. These boundaries are located far enough from the quarry to prevent any influence on the studied processes. Initial groundwater heads are constant all over the modelled area and 
equal the prescribed heads on the external limits. Natural groundwater recharge are neglected. Sinusoidal stresses are applied as prescribed fluxes on all cells corresponding to the open pit quarry.

In the following 'Results' section, several scenarios are considered, as a function of the hydraulic parameters values of the rock medium, the frequency and intensity of the sinusoidal stresses in the quarry, and the regional hydrogeological and geological contexts. All displayed results are considered when a 'steady periodic' state is reached, i.e. when the amplitude of the fluctuations is constant and not influenced by the initial conditions.

\section{Results}

\subsection{Pump-storage operations in homogeneous rock media}

The impact of cyclic pump - storage operations is first studied for a quarry located in a homogeneous rock media. This case study is quite simple but enables to understand more easily the hydrogeological response of such systems.

Numerical calculations have been performed using specific quarry, rock and pump - storage properties. In the following paragraphs, results are presented using the non-dimensional formalism exposed in Section 2.3, and are based on the following parameters ranges. The squared quarry has horizontal dimensions between $100 \times 100 \mathrm{~m}$ and $200 \times 200 \mathrm{~m}$, and a saturated depth of $80 \mathrm{~m}$. Pump-storage stresses in the quarry are sinusoidal, with a frequency included between 1.6 and 24 cycles per day. Induced stresses are simulated for hydraulic conductivity ranging from $10^{-4}$ to $10^{-8} \mathrm{~m} \cdot \mathrm{s}^{-1}$, and specific yield ranging from 0.01 to 0.30 . Such ranges have been chosen according to expected properties in such a pump storage system. 
A.

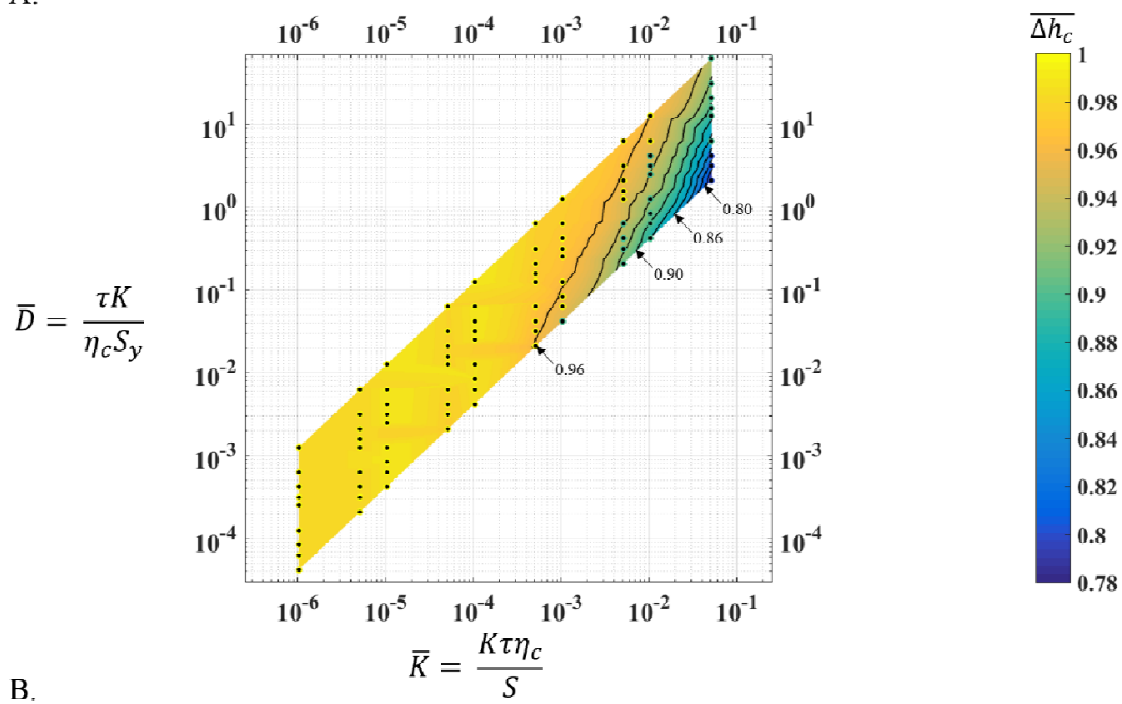

B.

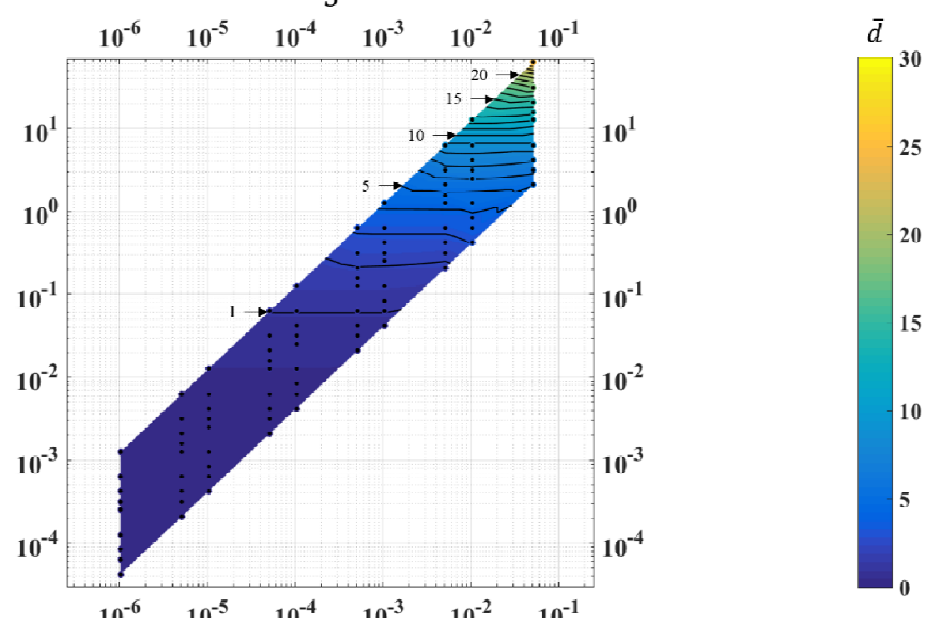

Figure 3. (A) Non-dimensional amplitude of the water level fluctuations in the quarry $\overline{\Delta \mathbf{h}_{\mathrm{c}}}$, according to the non-dimensional diffusivity $\bar{D}$ and exchange capacity $\bar{K}$. The range between two adjacent isovalue curves is equal to 0.02. (B) Non-dimensional distance of influence $\bar{d}$ in the rock media, according to the non-dimensional diffusivity $\overline{\mathbf{D}}$ and exchange capacity $\overline{\mathrm{K}}$. The range between two adjacent isovalue curves is equal to 1. The black dots correspond to couples of non-dimensional diffusivity and non-dimensional exchange capacity values, where the non-dimensional amplitude and non-dimensional distance of influence were actually simulated using the numerical model.

Figure $3 \mathrm{~A}$ and $\mathrm{B}$ show the non-dimensional amplitude of the water level fluctuations in the quarry $\overline{\Delta \mathrm{h}_{\mathrm{c}}}$, and the non-dimensional distance of influence $\overline{\mathrm{d}}$ in the rock media, as a function of the non-dimensional exchange capacity $\overline{\mathrm{K}}$ and the non-dimensional diffusivity $\overline{\mathrm{D}}$. These two graphs directly give the evolution of the two investigated variables as a function of the two non-dimensional parameters. The non-dimensional amplitude of the water level 
fluctuations in the quarry $\overline{\Delta \mathrm{h}_{\mathrm{c}}}$ decreases as $\overline{\mathrm{K}}$ increases and $\overline{\mathrm{D}}$ decreases (Figure 3A). Within the ranges of parameter values considered in this study, this non-dimensional amplitude varies between 1 and 0.78 . The unity value corresponds to an impermeable lower reservoir without any quarry - rock medium water exchange. The non-dimensional distance of influence increases with $\overline{\mathrm{D}}$ and is independent of $\overline{\mathrm{K}}$ (Figure 3B), as the isovalue curves are globally horizontal. This non-dimensional distance of influence is included between 0 and 30 for the considered parameters values.

The two graphs of Figure 3 also enable to analyse the impact of pump-storage systems as a function of all dimensional parameters defining $\overline{\mathrm{K}}$ and $\overline{\mathrm{D}}$. For any specific context related to the rock hydraulic properties, to the quarry dimensions, and the pump-storage configuration, results of Figure 3 allow specifying the potential water level fluctuations in the quarry and the distance of influence.

\subsubsection{Influence of the rock medium hydraulic properties}

A change of hydraulic conductivity implies a displacement along the 1/1 direction (Figure 3), as the hydraulic conductivity defines both $\overline{\mathrm{K}}$ and $\overline{\mathrm{D}}$ non-dimensional parameters (Equations 14 and 15). The amplitude of the water level fluctuations in the quarry decreases and the distance of influence in the rock increases, as the hydraulic conductivity of the rock increases. These effects are logically explained by higher water exchanges and an easier propagation of the induced stress in a more permeable rock media.

A change of specific yield implies a displacement along the vertical direction. When the specific yield value increases, both the amplitude of the water level fluctuations in the quarry (Figure 3A) and the non-dimensional distance of influence (Figure 3B) decreases, due to more important storage effects in the rock.

An equivalent increase in hydraulic conductivity and specific yield implies a displacement along the horizontal direction. In this context, the change regarding the water level fluctuations amplitude in the quarry is more important. Conversely, there is no effect on the non-dimensional distance of influence.

\subsubsection{Influence of the quarry dimensions}

Using a larger quarry and similar stresses logically induces smaller absolute fluctuations in the quarry and in the surrounding environment. Any pumped or injected water volume is actually distributed over a larger quarry volume. Additionally, the interface between the 
quarry and the rock media is also increased, inducing potentially different quarry - rock interactions.

To figure out the impact of the quarry dimensions in a more tangible way, a change of the quarry surface may be considered, keeping the parameter $\boldsymbol{\eta}_{\mathbf{c}}$ constant. In this case, the maximum value of the sinusoidal flow rate $\mathbf{Q}_{\max }$ is increased by the same ratio as the quarry surface $S$, so that water level fluctuations are only differing due to the potentially different quarry - rock media interactions.

A similar increase of $S$ and $\mathbf{Q}_{\text {max }}$ induces a decrease of $\overline{\mathbf{K}}$ and has no effect on $\overline{\mathbf{D}}$, resulting in a horizontal displacement, to the left, on the graphs of Figure 3. Therefore, the nondimensional amplitude of the water level fluctuations in the quarry increases, towards the unity value. In other words, the attenuation of the water level fluctuations in the quarry is relatively less important for a larger quarry. This observation may be explained by the fact that the water volumes exchanged between the quarry and the rock media increase with the perimeter of the quarry. These volumes are however distributed over the whole quarry surface, which increases faster than the perimeter. In a similar context, keeping the parameter $\boldsymbol{\eta}_{\mathbf{c}}$ constant, the non-dimensional distance of influence in the rock media is not influenced by the quarry surface.

\subsubsection{Impact of the frequency of the pump-storage stresses in the quarry}

The frequency of the pumping/injection flow rates, prescribed in the quarry, is depending on the electricity market prices and on the instantaneous regional electricity production and demand. This frequency is therefore variable across the day, but may be approximately considered as included between one and a few hours (European Commission, 2017).

The impact of the frequency may be discussed on the graphs of Figure 3, in a similar way as for the quarry dimensions, keeping the parameter $\boldsymbol{\eta}_{\mathbf{c}}$ constant. In this context, $\mathbf{Q}_{\max }$ must vary in the same proportion as the frequency, or in inverse proportion to the period $\tau$. It also means that the same water volumes are pumped/injected during a single pump - storage cycle.

An increase of the period $\tau$ (a decrease of the frequency), keeping $\eta_{c}$ constant, induces a similar increase of $\overline{\mathrm{K}}$ and $\overline{\mathrm{D}}$, resulting in displacement along the 1/1 direction, towards the topright graphs corners (Figure 3). These changes result in a decrease of the non-dimensional amplitude of the water level fluctuations in the quarry, and an increase of the non-dimensional 
distance of influence. In other words, results generally show that the interactions quarry rock media are more important, in terms of exchanged groundwater volumes and distance of propagation, with the decrease of the pump/storage stresses frequency.

\subsubsection{Impact of a regional hydraulic head gradient}

At the scale of the modelled area, a regional groundwater head gradient is usually observed, and induces natural groundwater flow around open pit quarries. To assess the influence of this regional gradient on the water level fluctuations in the quarry, and on the distance of influence in the rock media, all simulations performed in previous sections were reproduced, considering a uniform hydraulic gradient ranging from $0.1 \%$ to $2 \%$, over the modelled area. These gradient values are commonly observed in Belgian aquifers (Dassargues and Walraevens, 2014). For all models and simulations, the amplitude of the water level fluctuations in the quarry, and the distance of influence upstream and downstream the quarry have been calculated.

Results (not shown here) indicate that the amplitude of the water levels fluctuations in the quarry is similar to the corresponding homogeneous case without regional hydraulic head gradient. Regarding the environmental impact around the quarry, the distance of influence upstream the quarry is slightly longer than downstream. However, the difference, compared to the corresponding case without regional gradient, is very small. In all cases and simulations, this difference is lower than $2 \%$.

\subsection{Pump-storage operations in heterogeneous rock media}

The heterogeneity of the hydraulic properties may influence substantially the flow and propagation of any stress in the rock media. The objective is here to understand and quantify the impact of a single fracture on a pump-storage system, regarding the water level fluctuations in the quarry and the distance of influence in the surrounding rock media. To assess this impact, a linear fracture is introduced in the model grid using an equivalent porous media approach. The width of the fracture is supposed to be the width of a grid cell row. The equivalent hydraulic conductivity and porosity are calculated using the following Equations.

The transmissivity of the fracture $\mathrm{T}_{\text {frac }}$ is calculated using the Poiseuille flow equation.

$$
\mathrm{T}_{\text {frac }}=\frac{\rho g\left(\mathrm{a}_{\mathrm{frac}}\right)^{3}}{12 \mu}
$$




$$
\begin{array}{lll}
\rho & : & \text { density of water }\left[\mathrm{kg} \cdot \mathrm{m}^{-3}\right] \\
\mathrm{g} & : & \text { acceleration due to gravity }\left[\mathrm{m} \cdot \mathrm{s}^{-2}\right] \\
\mathrm{a}_{\mathrm{frac}} & : & \text { aperture of the fracture }[\mathrm{m}] \\
\mu & : & \text { dynamic viscosity of water }\left[\mathrm{kg} \cdot \mathrm{m}^{-1} \cdot \mathrm{s}^{-1}\right] .
\end{array}
$$

The equivalent hydraulic conductivity of the fracture $\mathrm{K}_{\mathrm{frac}}$ is calculated as:

$$
\begin{aligned}
& \mathrm{K}_{\text {frac }}=\frac{\mathrm{T}_{\text {frac }}}{\mathrm{a}_{\text {cell }}} \\
& \mathrm{a}_{\text {cell }}: \text { width of the cells row where the fracture is implemented }[\mathrm{m}] .
\end{aligned}
$$

The equivalent specific yield of the fracture $S_{y}$ frac is calculated as:

$$
\mathrm{S}_{\mathrm{y} \text { frac }}=\frac{\mathrm{a}_{\mathrm{frac}}}{\mathrm{a}_{\text {cell }}} .
$$

The influence of the fracture is assessed as a function of its hydraulic properties and position. The case of a fracture intersecting perpendicularly the quarry walls is first considered, with different fracture apertures $\left(1 \times 10^{-2} \mathrm{~m}, 1 \times 10^{-3} \mathrm{~m}\right.$ and $\left.1 \times 10^{-4} \mathrm{~m}\right)$. Secondly, the case of a nonintersecting fracture is also investigated, with different quarry - fracture distances $(1 \mathrm{~m}, 5 \mathrm{~m}$ and $10 \mathrm{~m}$ ). In all cases, the fracture crosses the whole modelled domain from the quarry to the external boundary.

\subsubsection{Influence of a fracture connected to the quarry}

The influence of the fracture depends on its aperture, and related transmissivity. Regarding the amplitude of the water level fluctuations in the quarry, the presence of a single fracture however has a limited impact. This amplitude only slightly decreases with the increase of the fracture aperture. Taking into account all quarry dimensions and rock media properties considered in this study, and a very large fracture aperture of $0.1 \mathrm{~m}\left(\mathrm{~T}_{\text {frac }}=8.1 \times 10^{2} \mathrm{~m}^{2} . \mathrm{s}^{-1}\right)$, the maximal difference between the simulated normalized amplitude, with and without a fracture, is lower than $0.1 \%$, following the small impact of the fracture on the overall aquifer storage. Nevertheless, note that the presence of several fractures, fractured zones, or karstic conduits could affect more significantly the storage and water levels in the quarry. Their presence and spatial distribution must be studied at the scale of any quarry used for pump - storage systems.

Although the influence on the water level fluctuations in the quarry is small, the presence of a single fracture may nevertheless locally induce a more significant impact on the amplitude of 
the groundwater level fluctuations. As the aperture of the fracture, and its related transmissivity, increases, a preferential flow path develops and locally extends the distance of influence. This effect is clearly shown in Figure 4, as a function of the fracture aperture, for several cases corresponding to a pump - storage cycle period of 10 hours, a quarry surface of $100 \times 100 \mathrm{~m}$, and $\mathrm{Q}_{\max }$ equal to $25 \mathrm{~m}^{3} . \mathrm{s}^{-1}$. This local distance of influence also depends on the hydraulic properties of the adjacent rock matrix. The groundwater level fluctuations generated and propagating in the fracture, actually dissipate in the bordering rock matrix, following the same processes as those reported in Section 3.1. As presented in Figure 4, the nondimensional distance of influence $\bar{d}$ in the fracture increases with the decrease of the rock matrix transmissivity and specific yield (or decrease of $\overline{\mathrm{K}}$ and/or $\overline{\mathrm{D}}$ ). Generally, depending on these properties and the aperture of the fracture, the non-dimensional distance of influence may sharply increase, compared to the non-dimensional distance of influence in the porous rock media. The affected area around the fracture increases with the diffusivity of the rock matrix $\overline{\mathrm{D}}$. Note that for very thin fractures, results correspond to the homogeneous cases. The impact of the fracture becomes logically visible when the equivalent hydraulic conductivity of the fracture $\mathrm{K}_{\mathrm{frac}}$ is greater than the matrix hydraulic conductivity. Note also that calculations are not yet relevant when the distance of influence goes beyond the limits of the modelled area and interacts with the prescribed boundary conditions. On the graph of Figure 4, this limit approximately corresponds to a non-dimensional distance of influence equal to 125 .

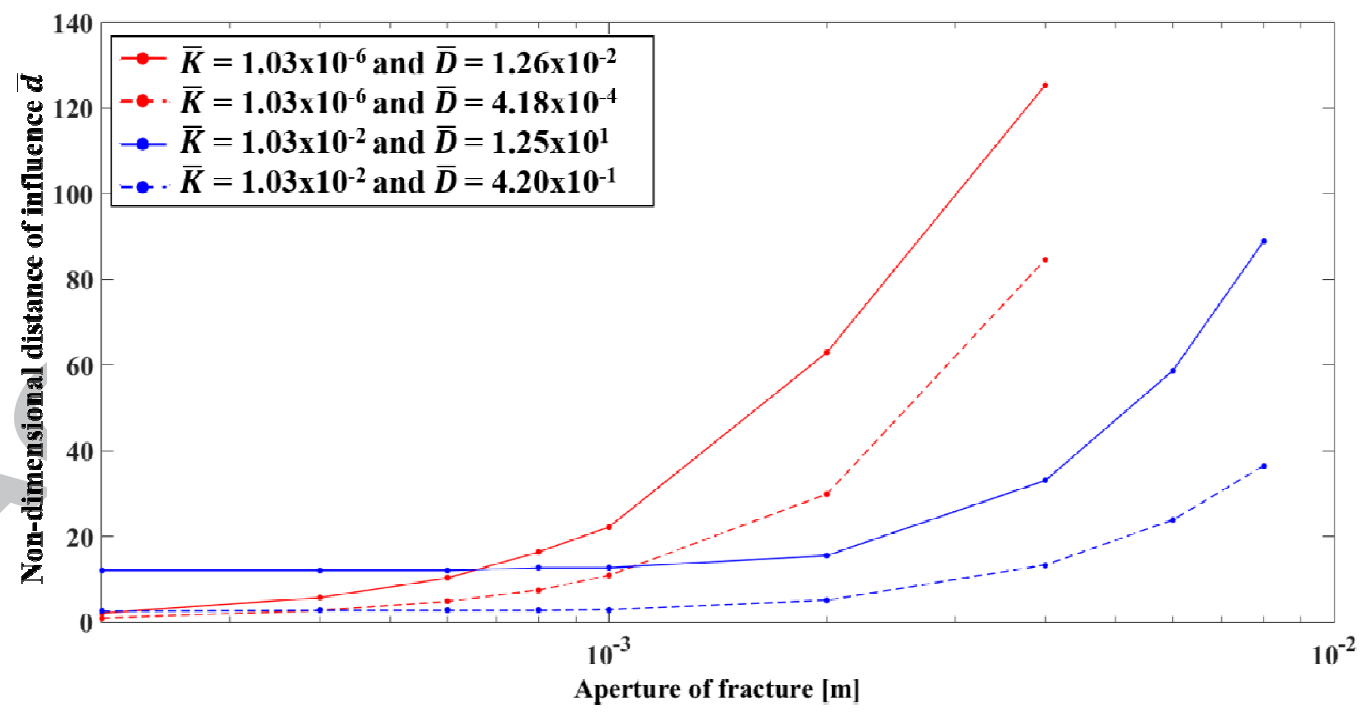

Figure 4. Calculated non-dimensional distance of influence $\overline{\mathbf{d}}$ in the fracture, as a function of the fracture aperture, for different values of the rock matrix $\bar{K}$ and $\bar{D}$. 


\subsubsection{Influence of a fracture disconnected from the quarry}

This section investigates the impact of a fracture located at a specific distance from the quarry. The implemented fracture is still perpendicular to the quarry walls but is limited in space and does not intersect it. Figure 5 shows the calculated 'distance of influence' in the fracture direction, as a function of its distance to the quarry, for different cases of rock matrix hydraulic properties. In this example, the aperture of the fracture is equal to $4 \times 10^{-3} \mathrm{~m}$, to maximise the potential effects of the fracture, within the range of values for which interactions with the domain limits remain negligible. Note that when the distance between the quarry and the fracture is equal to zero, the results correspond to the case of an intersecting fracture (see previous Section 3.2.1 for comparison). Results shown in Figure 5 are interpreted as the propagation of the groundwater level fluctuations in two successive different media (the rock matrix and the fracture). If the fracture is located beyond the nondimensional distance of influence $\overline{\mathrm{d}}$ corresponding to the homogenous rock matrix, the effect of the fracture is logically not visible. This is clearly illustrated in Figure 5 for the rock matrix characterized by a low non-dimensional exchange capacity $\overline{\mathrm{K}}$ (red curves). For this rock matrix, the distance of influence is very short and equal to a few meters (see Section 3.1). As a consequence, when the fracture is moved away from the quarry walls, the distance of influence rapidly drops from the high values corresponding to the case where the fracture is connected to the quarry (Section 3.2.1), to the low values corresponding to the homogeneous rock media. If the fracture is located within the distance of influence corresponding to the homogenous rock matrix, the fracture induces a local distortion and an elongation of the impacted area. Between the quarry and the fracture, groundwater level fluctuations are first attenuated in the porous rock matrix. The residual fluctuations then propagate in the fracture. This effect can be observed on the blue curves of Figure 5, which correspond to a rock matrix characterized by a non-dimensional exchange capacity $\overline{\mathrm{K}}$ of $10^{-2}$ and two different nondimensional diffusivity $\overline{\mathrm{D}}$ values. For these cases, the influence of the fracture remains strong, even if this fracture is disconnected from the quarry. For longer distances between the quarry walls and the fracture, the distance of influence tends again to values corresponding to the homogeneous cases. As a conclusion, the influence of disconnected fractures on the shape of the zone impacted by pump - storage operations appears limited in many cases, and strongly depends on the rock matrix hydraulic properties. From a general point of view, and considering realistic rock properties, favourable conditions to observe a significant influence would correspond to high values of $\overline{\mathrm{D}}$ and small values of $S_{y}$. This case may combine large 
zones around the quarry where disconnected fractures remain influent; and adequate conditions for pressure propagation into the fracture.

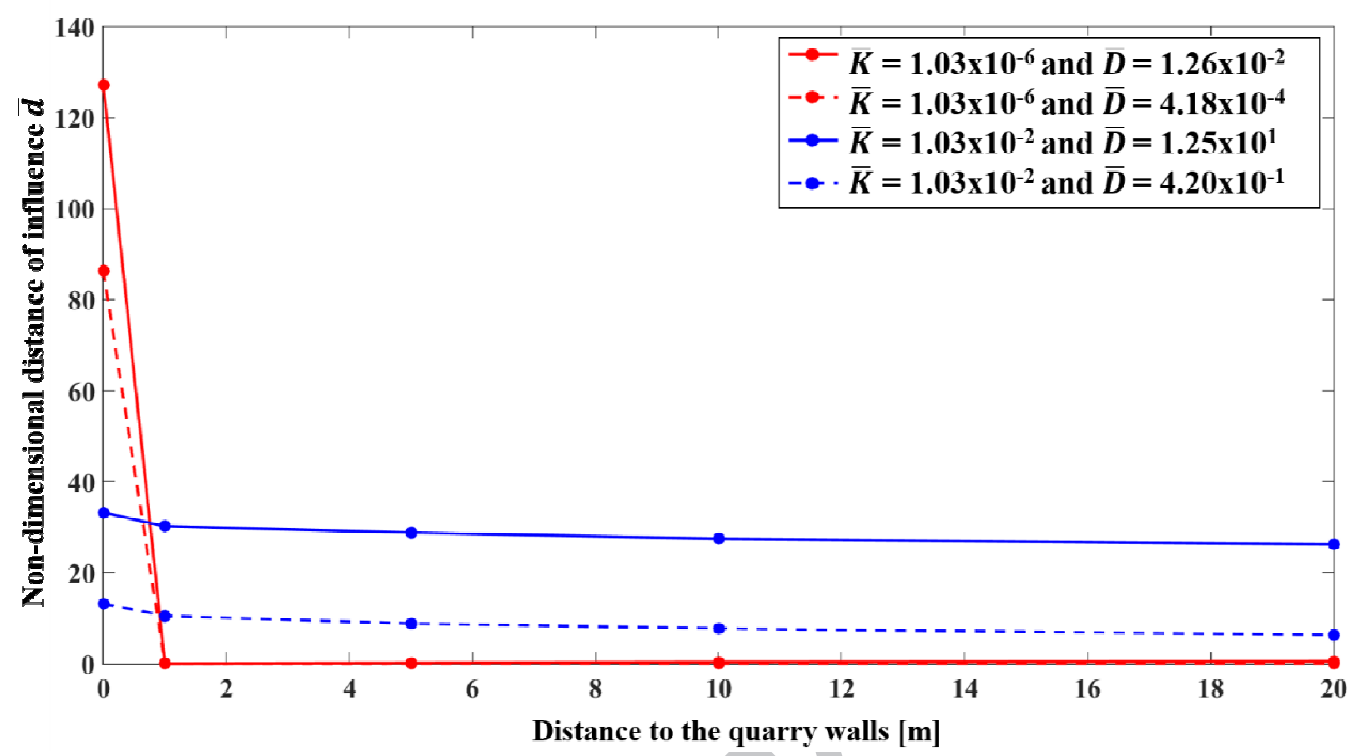

Figure 5. Non-dimensional distance of influence in a fracture located at a specific distance from the quarry walls. The aperture of the fracture is equal to $4 \times 10^{-3} \mathrm{~m}$. Different cases of rock matrix hydraulic properties are considered.

\section{Discussions}

In terms of pump-storage application, the results presented above show that the impact of geology and hydrogeology on the water level fluctuations in the quarry are somehow limited. Considering the used values in Figure 3, the non-dimensional amplitude of the water level fluctuations in the quarry $\overline{\Delta \mathrm{h}_{\mathrm{c}}}$ is included between 1.00 and 0.78 . Values lower than 1.00 are explained by exchanged groundwater volumes during pump - storage cycles, between the quarry and the rock medium. The lowest value correspond to the most permeable and most porous rocks. In the worst case, it corresponds to a decrease of $22 \%$. However small, this difference may be important regarding the hydroelectricity production, the system setup and its profitability (Pujades et al., 2017). The evolution through time of the water level in the quarry actually also influences the maximum drop of elevation between the upper and lower reservoirs, which determines the electricity power production. This may be particularly significant if the elevation difference between the two reservoirs is small, compared to the water level fluctuation amplitude in the quarry. Calculating accurately these expected 
fluctuations is also important to setup running operations, especially regarding the location of particular equipment such as turbines or water pumping pipes. Finally, planning accurately these fluctuations enables to manage possible stability issues, which may occur along the quarry walls or within old backfills, frequently observed in rock exploitations.

The distance of influence is much more sensitive. In Figure 3B, the non-dimensional distance of influence $\overline{\mathrm{d}}$ around the quarry is included between 0.5 and 25 . Higher values correspond to more permeable and less porous rocks. As shown in Section 3.2, this distance of influence may become substantially larger in the presence of heterogeneities such as specific fractures or conduits, intersecting the quarry. The influence area of the cyclic stresses around the quarry thus appears to be the most constraining geological factor when designing new pump-storage systems. The impact of induced water level fluctuations in the rock media must be verified, and pump-storage systems must be developed considering the different actors and the possible hazard or end-users conflicts, which could occur within this distance. As examples, they ideally must not interact with other existing pumping installations. Any stability problems such as soil subsidence or collapse must also be studied. This is particularly problematic in limestone formations, where potentially unstable weathered of karstified rocks are regularly observed (Kaufmann and Quinif, 2002). All these aspects may become critical factors, especially in highly urbanized countries such as Belgium.

To limit this distance of influence, operators may potentially adapt the maximum pump storage flow rate $Q_{\max }$ and the cycles frequency $\frac{1}{\tau}$. Imposing a minimum frequency would actually constitute an efficient strategy to decrease the distance of influence and mitigate the impact of pump - storage operations on the environment (Section 3.1.3). The stresses frequency historically operated in some existing high-voltage pump - storage electrical stations is about two cycles a day. In this case, the objective is mainly to manage the higher electricity demands in the morning and the evening. Currently, the idea of implementing medium-voltage stations across the territory is also to be able to accommodate the intermittent energy production from renewable sources (ex. wind turbines, photovoltaic systems). In this context, the frequency of the pumping/injection cycles in the quarry are expected to be much more variable, including higher frequency values, potentially contributing to less important distance of influence.

Despite potential obstacles that may complicate the practical implementation of pump storage systems in quarries, many development possibilities seem to exist. In South of 
Belgium (Walloon Region - $16844 \mathrm{~km}^{2}$ ), Poty and Chevalier (2004) have inventoried almost one thousand open pit quarries located in the administrative and official extracting areas. Although many other sites exist (Remacle, 2009), this inventory generally gathers the most important open pits in terms of dimensions. Among them, about $25 \%$ are actually still operated. Topographic conditions would allow developing pump-storage systems in some of these sites. They may be imagined in the old flooded quarries, or even in the quarries still in operations with dewatering. In this latter case, the whole depth of the open pit could potentially be used, maximizing the elevation drop between the upper and lower reservoir, but a large part of the quarry should however be reserved for water storage and excluded from any extracting operation. Quarries are located in various rock types (Poty and Chevalier, 2004), with different hydraulic properties and dimensions. For illustration purpose, Table 1 shows four simplified examples, representative of the variety of existing quarries, where pump-storage systems could possibly be installed. Pumping - injection sinusoidal stresses, characterized by a period of 10 hours and a maximum flow rate of $25 \mathrm{~m}^{3} . \mathrm{s}^{-1}$ have been simulated in each of them.

\begin{tabular}{|c|c|c|c|c|}
\hline & Ex. 1 & Ex. 2 & Ex. 3 & Ex. 4 \\
\hline Lithology & Chalk & Limestone & Crystalline rock & Sandstone \\
\hline $\begin{array}{l}\text { Dimensions }[\mathrm{m}] \\
\text { (Length } \times \text { Width } \times \text { water depth) }\end{array}$ & $500 \times 500 \times 20$ & $175 \times 175 \times 40$ & $800 \times 800 \times 120$ & $100 \times 100 \times 30$ \\
\hline $\begin{array}{l}\text { Elevation drop potentially } \\
\text { available }[\mathrm{m}]\end{array}$ & 40 & 100 & 120 & 50 \\
\hline Hydraulic conductivity $\left[\mathrm{m} . \mathrm{s}^{-1}\right]$ & $10^{-4}$ & $10^{-4}$ & $10^{-7}$ & $10^{-5}$ \\
\hline Specific yield [-] & 0.16 & 0.16 & 0.05 & 0.14 \\
\hline $\begin{array}{l}\text { Amplitude of the water level } \\
\text { fluctuations in the quarry } \Delta \mathrm{h}_{\mathrm{c}} \\
\text { [m] }\end{array}$ & 1.14 & 9.11 & 0.45 & 27.71 \\
\hline $\begin{array}{l}\text { Maximal distance of influence } \\
\text { from the quarry walls } d[\mathrm{~m}]\end{array}$ & 57 & 82 & 6 & 27 \\
\hline $\begin{array}{l}\text { Theoretical water level } \\
\text { fluctuation in an impermeable } \\
\text { quarry } \eta_{c}[\mathrm{~m}]\end{array}$ & 1.15 & 9.35 & $\sim 0.45$ & 28.65 \\
\hline $\begin{array}{l}\text { Non-dimensional amplitude of } \\
\text { the water level fluctuations in } \\
\text { the quarry } \overline{\Delta \mathrm{h}_{\mathrm{c}}}[-]\end{array}$ & 0.99 & 0.97 & $\sim 1$ & 0.97 \\
\hline $\begin{array}{l}\text { Maximal non-dimensional } \\
\text { distance of influence the quarry }\end{array}$ & 49.56 & 8.77 & 13.33 & 0.94 \\
\hline
\end{tabular}


walls $\overline{\mathrm{d}}[-]$

Table 1. Main characteristics of simplified cases, representative of existing quarries where pump - storage systems could possibly be installed (DGARNE, 2017).

Figure 6 presents the simulated absolute amplitude $\Delta \mathrm{h}$ of the groundwater level fluctuations in the rock medium, as a function of the distance to the quarry walls. Dimensional and more tangible results regarding water fluctuations in the quarry, distance of influence, and theoretical electrical power delivered are also presented in Table 1. These results corroborate the conclusions of Section 3.1. The distance of influence is generally larger for the rocks with the highest hydraulic conductivity values. Note that the amplitude of the water level fluctuations in the quarry (i.e. at $\mathrm{x}=0$ ) are not normalized here, and are consequently primarily controlled by the open pit surface. The larger the quarry, the smaller the absolute amplitude.

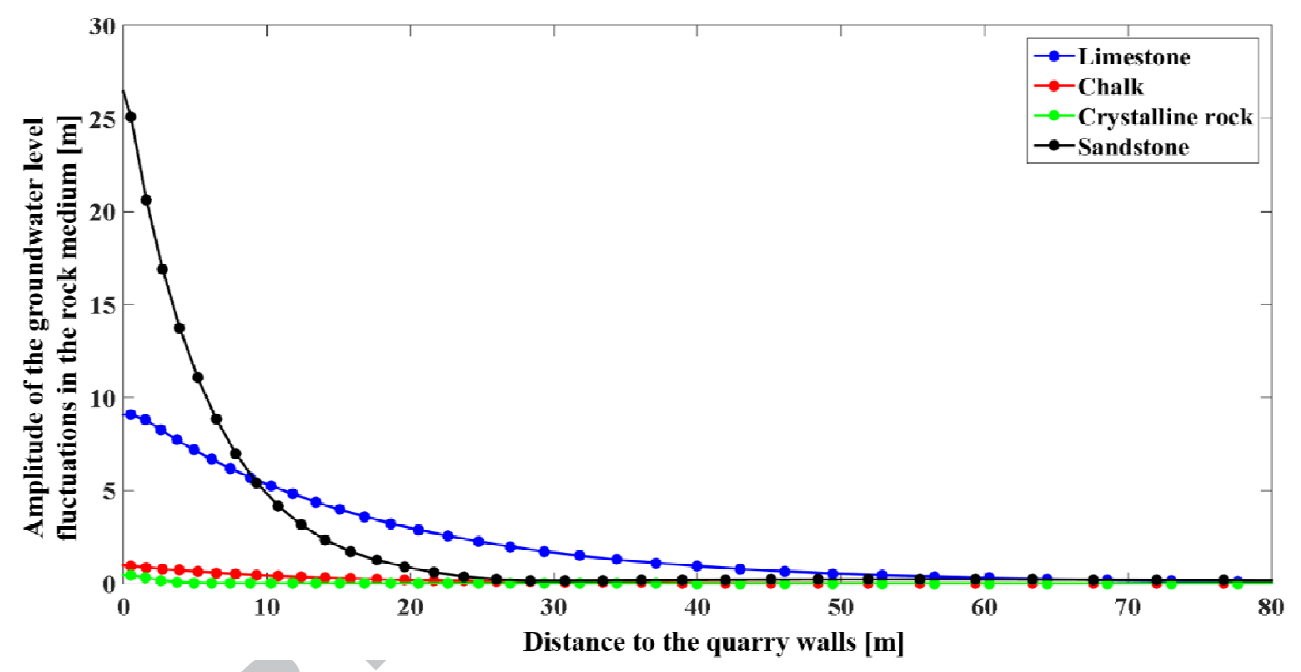

Figure 6. Simulated amplitude of the groundwater level fluctuations in the rock medium, as a function of the distance to the quarry walls, for the 4 specific examples of Table 1

Specific hydrogeological studies will be needed to design future pump - storage systems in any existing quarry, in order to accommodate all specific conditions of the site. Each quarry has a specific surface, depth, shape, geological structure, rock texture, etc., and it was not possible or the objective, in this study, to consider all these specificities. Nevertheless, presented results give guidelines on the most constraining issues of the problem. Considering the water volumes needed to reach a minimum cost-effective power production, quarries smaller than $100 \times 100 \mathrm{~m}$ might hardly be used for pump - storage applications. Using larger quarries, the values of amplitude attenuation and distance of influence play an important role in the design of systems. Results calculated above for a homogeneous medium or for single fractures, can be viewed as a first step for impact and feasibility assessment of the problem. 
Considering more realistic and complex conditions, in terms of shape, hydrogeology, fractures, is however necessary to specify impacts.

\section{Perspectives and conclusions}

This study allowed assessing the hydrogeological interactions between a flooded open pit quarry and the surrounding unconfined rock media, in the context of a pump - storage system implementation. In particular, numerical simulations were conducted to investigate the influence of the hydrogeological properties and the pump - storage system parameters on these interactions. In a broader context, most of previous studies about oscillatory pumping tests have generally focused on confined aquifers and smaller scales.

Results of this study have shown that hydrological quarry - rock interactions must be considered with caution. For rock media characterized by high hydraulic conductivity and porosity values, water volumes exchanges during cycles may affect significantly the amplitude of the water level fluctuations in the quarry, and as a consequence, the instantaneous electricity production. Results have shown that this effect is also greater as the surface of the lower reservoir is small. With realistic hydraulic parameters values, and quarries not smaller than $100 \times 100 \mathrm{~m}$, the expected impact on the water level fluctuations reaches maximum $22 \%$ of the head fluctuations in an ideal quarry without loss in the aquifer. Some authors have also evoked the possibility to use old underground mines (ex. abandoned coal mine) to implement pump - storage systems (e.g. Bodeux et al., 2017; Pujades et al., 2016). In this case, the elevation drop between the upper and lower reservoirs, thus the instantaneous produced electrical power, could potentially be higher. Involved volumes and the equivalent surface of the shafts and galleries could conversely be substantially smaller, maximizing the water level fluctuations in the mine. Bodeux et al. (2017), investigate the possibility to use an underground slate mine for pump - storage systems. They have also highlighted the influence of these water exchanges on the efficiency of the system.

This present study has also assessed the impact of the pump - storage cyclic stresses on the environment surrounding the quarry. The distance of influence is potentially high under specific conditions, and may be enhanced with the occurrence of rock heterogeneities. The presence of fractures intersecting the quarry is crucial. They may affect locally, but significantly, the distance of influence of the pumping/injecting operations. The impact around the stressed quarry thus appears as an important constraining factor regarding the feasibility of pump - storage systems, to be assessed carefully if groundwater level fluctuations around the quarry are expected to bring adverse effects. 
The implementation of a pump - storage system in a flooded quarry imposes to characterize in details the hydraulic properties and structure of the surrounding rock media. Conducting cyclic field tests in the related geological formations may help performing this task. This kind of tests are however usually carried out at much smaller spatial and time scales (Guiltinan and Becker

, 2015; Rabinovich et al., 2015; Rasmussen et al., 2003). The question thus arises about the representativeness of achieved measurements and results, in the context of pump - storage systems in quarries. Moreover, some authors have also highlighted a possible drift of calculated hydraulic parameters, as a function of the stresses frequency. Therefore, performing real-case experiments, with relevant frequencies and amplitudes could bring highly interesting information for a more realistic impact study. This kind of large scale oscillatory pumping experiment would also provide opportunities for characterizing the largescale spatial distribution and structure of hydraulic properties around the quarry, by inversion of the measured cyclic data at different observation points.

Finally, this study has shown that development of pump - storage systems in flooded quarries, for hydroelectricity production is possible from a hydrogeological perspective under specific conditions. Additional steps rely on the assessment of the other technical aspects, such as the electromechanical equipment, the integration of the produced electricity in the power distribution grids, the adequacy with the power demand, and finally yet importantly, costbenefit aspects of such projects.

\section{Acknowledgements}

This research has been supported by the Public Service of Wallonia, Department of Energy and sustainable Building, in the framework of the SMARTWATER project. 


\section{References}

Bakhos, T., Cardiff, M., Barrash, W., Kitanidis, P.K., 2014. Data processing for oscillatory pumping tests. J. Hydrol., 511: 310-319.

Bakker, M., 2009. Sinusoidal pumping of groundwater near cylindrical inhomogeneities. Journal of Engineering Mathematics, 64(2): 131-143.

Black, J.H., Kipp, K.L., 1981. Determination of hydrogeological parameters using sinusoidal pressure tests: A theoretical appraisal. Water Resour. Res., 17(3): 686-692.

Bodeux, S., Pujades, E., Orban, P., Brouyère, S., Dassargues, A., 2017. Interactions between groundwater and the cavity of an old slate mine used as lower reservoir of an UPSH (Underground Pumped Storage Hydroelectricity): A modelling approach. Eng. Geol. 217, 71-80. https://doi.org/10.1016/j.enggeo.2016.12.007

DGARNE, 2017. Carte hydrogéologique de Wallonie [WWW Document]. Carte Hydrogéologique Wallonie. URL http://environnement.wallonie.be/cartosig/cartehydrogeo/application.htm\# ～(accessed 1.29.18).

Cardiff, M., Bakhos, T., Kitanidis, P.K., Barrash, W., 2013. Aquifer heterogeneity characterization with oscillatory pumping: Sensitivity analysis and imaging potential. Water Resour. Res., 49(9): 5395-5410.

Connolly, D., 2010. The integration of fluctuating renewable energy using energy storage. PhD thesis Thesis, Department of Physics and Energy. University of Limerick.

Dassargues, A., Walraevens, K., 2014. Watervoerende lagen \& grondwater in België Aquifères \& eaux souterraines en Belgique. Academia Press, pp. 472. 
Dupuit, J., 1863. Etudes théoriques et pratiques sur le mouvement des eaux dans les canaux découverts et à travers les terrains perméables (Theoretical and practical studies on the movement of water in uncovered canals and permeable terrains). Dunod, Paris.

Eberts, S.M., Bair, E.S., 1990. Simulated Effects of Quarry Dewatering Near a Municipal Well Field. Groundwater, 28(1): 37-47.

European Commission, 2017. Energy storage - The role of electricity. Commission Staff Working Document SWD2017_61.

Guiltinan, E., Becker, M.W., 2015. Measuring well hydraulic connectivity in fractured bedrock using periodic slug tests. J. Hydrol., 521: 100-107.

Harbaugh, A.W., 2005. MODFLOW-2005, The U.S. Geological Survey modular groundwater model - The Ground-Water Flow Process. U.S. Geological Survey Techniques and Methods 6-A16, U.S. Geological Survey.

Kaufmann, O., Quinif, Y., 2002. Geohazard map of cover-collapse sinkholes in the 'Tournaisis' area, southern Belgium. Engineering Geology, 65(2-3): 117-124.

Lee, C.I., Song, J.J., 2003. Rock engineering in underground energy storage in Korea. Tunnelling and Underground Space Technology, 18(5): 467-483.

Lepage, N., Hamel, P., Lefebvre, R., Themen, R., Biais, C., 1999. Decision analysis for leachate control at a fractured rock landfill. Ground Water Monitoring and Remediation, 19(3): 157-170.

Madlener, R., Specht, J., 2013. An exploratory economic analysis of underground pumpedstorage hydro power plants in abandoned coal mines. FCN working paper no. 2/2013, Institute for Future Energy Consumer Needs and Behavior, RWTH Aachen University, Aachen, Germany. 
Poty, E., Chevalier, E., 2004. L'activité extractive en Wallonie. Situation actuelle et perspectives. Rapport, Ministère de la Région wallonne, Direction générale de l'Aménagement du territoire, du Logement et du Patrimoine.

Pujades, E., Orban, P., Bodeux, S., Archambeau, P., Erpicum, S., Dassargues, A., 2017. Underground pumped storage hydropower plants using open pit mines: How do groundwater exchanges influence the efficiency? Applied Energy, 190: 135-146.

Pujades, E., Willems, T., Bodeux, S., Orban, P., Dassargues, A., 2016. Underground pumped storage hydroelectricity using abandoned works (deep mines or open pits) and the impact on groundwater flow. Hydrogeol. J., 24(6): 1531-1546.

Rabinovich, A., Barrash, W., Cardiff, M., Hochstetler, D.L., Bakhos, T., Dagan, G., Kitanidis, P.K., 2015. Frequency dependent hydraulic properties estimated from oscillatory pumping tests in an unconfined aquifer. J. Hydrol., 531: 2-16.

Rasmussen, T.C., Haborak, K.G., Young, M.H., 2003. Estimating aquifer hydraulic properties using sinusoidal pumping at the Savannah River site, South Carolina, USA. Hydrogeol. J., 11(4): 466-482.

Rehman, S., Al-Hadhrami, L.M., Alam, M.M., 2015. Pumped hydro energy storage system: A technological review. Renewable and Sustainable Energy Reviews, 44: 586-598.

Remacle, A., 2009. Contribution des anciennes carrières à la biodiversité wallonne. Convention "Les carrières en Région wallonne: inventaire et intérêt biologique" (C45). Rapport non publié, Service public de Wallonie, Direction générale opérationnelle de l'Agriculture, des Ressources naturelles et de l'Environnement, Direction de la Nature.

Renner, J., Messar, M., 2006. Periodic pumping tests. Geophysical Journal International, 167(1): 479-493. 
Severon, M.J., 2011. Preliminary evaluation of establishing an underground taconite mine to be used later as a lower reservoir in a pumped hydro energy storage facility on the mesabi iron range minnesota.

Uddin, N., Asce, M., 2003. Preliminary design of an underground reservoir for pumped storage. Geotechnical and Geological Engineering, 21(4): 331-355. 


\section{Highlights}

- Pump Hydro Energy Storage (PHES) systems in groundwater flooded quarries are studied

- Numerical simulation is used to study the environmental impact of these systems

- Groundwater head fluctuations in the quarry and the adjacent aquifer are simulated

- Distance of influence of PHES system in the surrounding rock media is calculated

- Feasibility of PHES in quarries is deduce according to the rock hydraulic parameters 